\title{
Textbook Evaluation of 'Economic and Developmental Study' Using Bloom Taxonomy
}

\author{
Rivaatin Mila Pratiwi ${ }^{1}$, I Nyoman Suparwa ${ }^{2}$, Made Sri Satyawati ${ }^{3}$ \\ goodmorningmaika@gmail.com \\ Udayana University, Denpasar 80114, Indonesia
}

\begin{abstract}
This research was conducted to evaluate ESP textbook, entitled 'Economic and Developmental Study', used by students of the Faculty of Economics, University of Muhammadiyah Malang by using Bloom's Taxonomy. In this case, The ESP aims to support students' mastery of English before they enter the professional world. Hence, textbook selection affects the development of learning effectiveness. It is expected that students can learn independently from the provided material inside textbooks. This research was aimed at analyzing the feasibility of the English for Economic and Developmental Studies textbook published by UMM Press using the Bloom Taxonomy cognitive approach. This research applied qualitative research that used a documentation method to collect the data. The results of the analysis showed that this book included Bloom's cognitive taxonomies: remembering, understanding, doing, analyzing, researching, and creating. Besides, this study also found that the presentation of material in the book was following Government Regulation (PP) No. 15 of 2009 concerning National Education Standards, namely: this textbook was able to (1) encourage student interaction for active learning, (2) there was a link between chapters, between subchapters, and between concepts, (3) there was an integration/harmony between concepts, and (4) presentation material was contextual.
\end{abstract}

Published by IJRP.ORG. Selection and/or peer-review under responsibility of International Journal of Research Publications (IJRP.ORG)

Keywords: Textbook Evaluation, ESP , Bloom Taxonomy

\section{Introduction}

Textbooks are considered to be a basic element that has an important and positive role in teaching and learning English daily (Hutchinson and Torres, 1994). Educators or teachers are expected to be able to make informed and correct decisions when they choose textbooks and supporting materials (Cunningsworth, 1995: 1). Because learning materials are 'the embodiment of the goals, values, and methods of a particular teaching and learning situation' (Hutchinson, 1987: 37). Textbook selection material usually involves the context of the material application as well as the needs and interests of educators and students. A textbook is considered to 

the goals and the needs of students, learning styles, proficiency levels, language teaching methods, classroom context, processes, and the potential for material to generate motivation, variations. and interests (Littlejohn, 1998: 190-1).

In the process of learning and teaching foreign languages, textbooks are considered to be able to provide guidance and cutting tools for practicing using the target language correctly (Tomlinson, 2012). In addition, textbooks can also function as a means of presentation, a reference source for practical activities and communicative interactions for students, a reference source for students, a syllabus, an independent learning resource, a source of independent access for students outside the classroom, and a source of support for educators who are lack of self-belief or experience in teaching (Cunningsworth, 1995). Most Indonesian schools use textbooks selected by teachers/education administrators and are available in the market by referring to the English curriculum and syllabus issued by the Ministry of National Education.

English for Economic and Developmental Studies is one of the textbooks published by UMM Press in 2018. This book is for the Department of Economics students, University of Muhamadiyah Malang (UMM), which aims to meet the needs of students to learn to communicate in English and/or while in the scope of work. This textbook consists of twenty-eight units. Each unit has a reading, writing, and speaking section. The reading section includes pre-reading, reading comprehension, and vocabulary exercises related to text topics. Next, the writing section contains the structure and sentence patterns and is equipped with writing exercises. Meanwhile, the last part is the speaking section, which contains exercise models and examples from practical activities. The type of English teaching program applied in this study is English for Specific Purpose (ESP), which is a type of approach to teaching English for specific scientific fields, such as medicine, nursing, or aviation. ESP aims to support students' mastery of English before they enter the professional world. Hence, textbook selection affects the development of learning effectiveness. It is expected that students can learn independently from the provided material inside textbooks.

There are two kinds of textbook evaluation: external evaluation and internal evaluation (McDonough et.al, 2013). External evaluation carries out an overview contained in the textbook. Meanwhile, internal evaluation is the analytical result between the suitability of external evaluation results and material organization as stated by the textbook's author. The textbook evaluation assesses textbook material suitability based on learning program aims and objectives; the effectiveness of using the material in teaching; the strengths and weaknesses of the textbook, the application of the textbook content. Therefore, educators, practitioners, textbook writers, or researchers should evaluate to see the significance of textbooks used for meeting student needs. To be able to carry out the teaching and learning process properly, educators need a framework or taxonomy. The taxonomy that is often used as a benchmark for teaching is Bloom's Taxonomy, which consists of six main categories: Knowledge, Comprehension, Application, Analysis, Synthesis, and Evaluation.

The English for Economic and Developmental Studies textbook has several sections which are repeatedly presented in every unit. For example, the word 'writing' that has been appeared in Unit 1 is displayed once again in Unit 2 to Unit 28 (the last unit). Other word examples, such as 'speaking' and 'reading' also experience similar consistent repetition. Hence, it can be assumed that the repeated displayed verbs are the main focus of this ESP book. However, it is necessary to study further whether the addition of this verb also adds to the feasibility of existing textbooks or vice versa.

Another reason for the importance of analyzing the ESP book made for UMM students is because UMM is the only private campus in Malang City publishing textbooks for its students. The learning objectives stated in the syllabus mention several dimensions of knowledge that are in the taxonomic table: meta-cognitive, procedural, and conceptual. However, the syllabus does not mention the accomplishments that will be achieved by students if they have completed the learning, especially cognitively as in Bloom's Taxonomy. The assessment of textbook feasibility has a juridical basis as stipulated in Government Regulation (PP) no. 19 of 2005 on National Education Standards. Article 43 paragraph 5 states that the feasibility standard of a textbook consists of the feasibility of the content, language, presentation, and graphics of the textbook. The content of the book refers to the content of the material in the textbook. Hence, the content of the material 
should follow the syllabus. In terms of content, this textbook only contains 3 sections: reading, writing, and speaking. However, the material used at the first meeting in the syllabus is listening via the YouTube platform. Therefore, based on this background, the researcher is interested in studying the feasibility of the English for Economic and Developmental Studies textbook published by UMM Press using the Bloom Taxonomy cognitive approach.

\section{Theoretical Framework}

Published material was considered insufficient. It did not always provide texts and a variety of activities that suited the needs of the class (Block: 1991). Other experts also argued that textbooks could shackle teachers' freedom in terms of teachers' activities and limit teachers' creativity when teaching (Prabhu: 1998); in addition, textbooks could also be used as a means of control for institutional interests (Bell and Gower, 1998: 117). Furthermore, Tomlinson (2011) said that textbooks were 'designed' primarily to satisfy the interests of administrators and teachers but in reality, it often ignored the needs and desires of students. In sum, teacher was nothing more than 'a cipher for a prepared text' (Hutchinson and Torres, 1994).

In the process of learning and teaching foreign languages, textbooks were considered as one type of language learning resource for students that provided information related to knowledge of the target language. Textbooks could offer correct target language guidance for students. Moreover, textbooks could also be regarded as a means of encouraging students to practice using the target language (Tomlinson, 2012). In addition, Cunningsworth (1995) also stated that textbooks could also function as a presentation tool, a reference source for practical activities for students and communicative interactions, a student reference source, syllabus, independent learning resources, independent access sources. for students outside the classroom, and a source of support for educators who lacked of confidence or experience in teaching. Therefore, every English textbook should be in accordance with the needs of learners and the objectives of the language learning program (Cunningsworth: 1995).

A qualified textbook should be able to facilitate the needs and learning processes of students, without having a tendency to use certain methods. In addition to these reasons, textbooks should also provide students with knowledge and effective use of the target language in various situations (during class and outside of class). In sum, there were two main roles of textbooks. First, textbooks were required to provide support to students by offering a variety of different types of texts, attractive visual displays (illustrations and designs), and supplemented with additional materials. Second, textbooks should also help teachers by providing ready made teaching materials, teaching ideas, reading texts, dialogues, and the like. Tarigan (2009:13) stated that textbooks were the learning material books used in certain subjects, which were used as the standard books compiled by experts. Furthermore, the Government Regulation (PP) No. 19 of 2005 concerning National Education Standards. Article 43 paragraph 5 explicitly mentioned that the feasibility standards of a textbook were composed of the appropriateness of the content, language, presentation and graphics of the textbook.

Moreover, Kinanti and Sudirman (2017), added that the feasibility of the content of the material was one of the four criteria for assessing the feasibility of textbooks that should be considered and adjusted to the regulations that have been set by the National Education Standards Agency (BSNP). Hence, textbooks became the main source in the teaching and learning process and were used as a reference for finding information and supporting learning activities by teachers and students. The commonly found problem with textbook was the lack of in-depth discussion of the material and content inadequacy.

To help educators carrying out the teaching and learning process well, a framework or a taxonomy was needed. It was the classification of objects according to certain characteristics. Etymologically, the word taxonomy came from the Greek word's taxis and nomos. Taxis means 'regulation or division' and nomos means law (Enghoff, 2009: 442). Hence, taxonomy could be interpreted as a law that governed something. It could be defined as a grouping of things based on a certain hierarchy (level). Where the higher taxonomy was more general and the lower taxonomy was more specific. According to Anderson and Krathwohl (2001:3-7) there were several uses of categorization in the framework work for education. First, it is allowed educators to 

possibilities of objectives in education. Third, it helped educators see the integral relationship between knowledge and cognitive processes inherent in learning objectives. Furthermore, Lee in Almerico and Baker (2004:3) also argued that taxonomy provided educators with an appropriate and general language reference that could articulate teaching goals in learning. One of the taxonomies commonly used in education was Bloom's Taxonomy. Theoretically, one of the reformers of Bloom's Taxonomy, Anderson and Krathwohl (2001:28-31) said that there were six (6) sub domains in Bloom's Taxonomy. The six sub-domains were then coded in the form of $\mathrm{C} 1$ to $\mathrm{C} 6$. As for each sub-domain of the cognitive domain Bloom's Taxonomy, namely:

1. Remember $(\mathrm{C} 1)$

2. Understand (C2)

3. Apply (C3)

4. Analyze (C4)

5. Evaluate (C5)

6. Create (C6)

Darmawan \& Sujoko (2013:37) explained that the additional taxonomy table included three important dimensions, namely the knowledge dimension, the cognitive dimension, and the psychomotor dimension. The cognitive dimension has at least 6 sub-dimensions. Meanwhile the affective dimension contained behaviors that emphasized aspects of feelings and emotions, such as interests, attitudes, appreciation, and ways of adjustment. Last, the psychomotor dimension consists of behaviors that are emphasized on the aspects of motor skills such as handwriting, typing, swimming, and operating machines. However, for this study, the author only uses the cognitive dimension as a theoretical basis for the author to analyze more deeply the feasibility of the ESP textbook used by the University of Muhammadiyah Malang (UMM).

\section{Methods}

This study used the descriptive qualitative method. It was the techniques of searching, collecting, comparing, and analyzing data (Yang, 2010: 25). In the application of qualitative descriptive methods, an appropriate data collection technique was needed, namely documentation. Documentation was a data collection technique by studying documents to obtain data or information related to the problem under study, (Sugiyono, 2009: 329). These documents could be in the form of letters, photo archives, meeting minutes, journals, diaries, and others. The data collection techniques performed by the author were: (1) determining the formulation of the topics to be researched and discussed using Bloom's Taxonomy; (2) conducting a preliminary general overview; (3) conducting an analysis using a cognitive approach from Bloom's Taxonomy. The author examined this textbook based on three parts that were always listed in each unit in the book, namely: reading, writing, and speaking section. The reading section consists of pre-reading, reading comprehension, and vocabulary exercises related to text topics. Meanwhile, the writing section contained the structure and sentence patterns which were complemented by writing exercises. The last speaking section included speaking models and practical exercises for students.

\section{Result and discussion}

\subsection{General Overview}

In terms of material content, this book was divided into three parts, namely reading, writing, and speaking. Furthermore, these materials were then inserted into 28 units. Hence, each unit contained three elements. The number of pages of this textbook was 452 pages, including the bibliography.

Table1. Material Placement in 'English for Developmental Studies Textbook' 


\begin{tabular}{|ll|l|l|}
\hline \multicolumn{2}{|c|}{ Content Material } & Unit & Element \\
\hline 1. & Reading & 28 Units & 3 elements \\
\hline 2. & Writing & 28 Units & 3 elements \\
\hline 3. & Speaking & 28 Units & 3 elements \\
\hline
\end{tabular}

In each unit, three skills should be accomplished by students: reading, writing and speaking. For example, in Unit 1, the reading material that should be studied was entitled, "four types of economic systems". This article consists of 7 paragraphs mentioning 4 economic models in the world: the traditional economic system, the market economic system, the command economic system, and the mixed economic system. Meanwhile, for the writing section, the given material was writing a short autobiography, and for the speaking section, the material given was a self introduction. Here, students were asked to introduce themselves in front of the class. The speaking, reading, and writing sections have consistently appeared in each unit, starting from unit 1 to unit 28 (the last unit). It's just that the material in the form of reading articles, writing material, and speaking material changes in each unit. For example, for unit 2, the reading article given was "Special Economic Zone" or in Indonesian, it means 'Special Economic Zone'. As for writing, the material given was descriptive writing. The example given in Unit 2 was how to describe the city of Tokyo, Japan (ESP, p. 25). Please note that for reading material, the articles listed were articles related to economics and business. As the unit of material increased, the given reading articles also became increasing complex. For example, in unit 28, the article was related to 'Factors that affected Human Resources Management' (ESP, p. 435) which was quite different than in Unit 1 (economic market type).

Next, this textbook also provided tasks for each section. The number of assignments given for each material, both reading, writing, and speaking, each ranged from 3 to 4 assignments. Apart from the tasks, vocabulary lists were also prepared to increase students' vocabulary. The entry number given in each unit was different. It ranged from 9 to 20 vocabularies per unit. These entries mostly came from articles on the reading material in each unit.

\subsection{Bloom's Taxonomy Cognitive Approach}

The content of the textbook was closely related to the learning material contained in the book. Textbook content was considered appropriate if the material did not contain elements of racial violence, pornography, and other materials that harm or incite certain groups. The ESP English for Developmental Studies textbook was divided into three parts, namely reading, writing, and listening.

\section{A. Reading}

The material in the reading section consists of articles composed of 7 to 10 paragraphs depending on the length or shortness of the article content and the article's topic was about economics and business. It then appeared from unit 1 to unit 28. The vocabulary or important vocabulary contained in the reading of the article was always placed at the end of the unit. There were 6 important indicators used to measure the appropriateness of the reading material content based on the Bloom Taxonomy cognitive approach. The first was the remembering process. In this process, students were expected to be able to recognize any information in the book as well as trying to retrieve it. The recognizing process started when students read the articles in the textbook, this textbook also helped students to easier understand the reading articles by pointing out the intended vocabulary.

Apart from recognizing, the retrieving process indirectly took place when students recalled key vocabulary which became the points of the reading. The process of retrieving reading material in each unit was not difficult because at the end of the reading section there was a special column for the vocabulary. Furthermore, every unit also provided assignments related to the articles being discussed. For example, in unit one task (task) 3, students were asked to redefine four global economic systems whose answers had been included in the reading article. The process of rewriting the meaning of these four economic systems was called a process 

understand or to comprehend. According to Anderson (2010: 40), a person could be assumed to understand when he was able to explain, classify, summarize/conclude the given material or reading. Hence, the assignments given in this textbook had already contained elements of explaining, classifying, summarizing, and other elements.

The third process was to apply or application. The process of application was the stage where the learning material was implemented by students. Unfortunately, for this process, the follow-up questions given only reached the remembering stage, they had not yet reached the application stage which was to reconstruct the events/information contained in the text. The following step was to analyze. Students were considered to be able to conduct an analysis once they were able to decipher and differentiate each component inside a global system. The cooperative words, such as to compare, to organize, to deconstruct, to outline, to invent, to construct, to combine, to examine, to assess, to experiment, to distinguish, to sort, to survey, to detect, to analyze, to classify were classified as analyzes section. For example, the reading article in Unit 9, entitled, "Inflation and Deflation, what is the Difference", helped students to analyze or to compare the difference between inflation and deflation.

The next level was C5 or evaluate. Evaluating meant making judgments based on predetermined criteria and standards. Students were expected to be able to examine existing problems comprehensively, criticize, and analyze each answer given. In reading the article entitled "Economic basics: supply and demand", the question was: (1) In your opinion, what is the correlation among the three aspects (supply, demand and price)? (2) If the price of the demand from consumers falls down, what will happen to the quantity of the supply from the producers? The last stage in Bloom's Taxonomy was to create, which was an effort to combine elements or parts into something new and whole so that an original product can be created. In the process of creating there was an effort to formulate a new framework of thought, planning, as well as reproducing new things from the material that had been received. However, the questions in the textbook did not force students to have the courage to build their arguments independently. Nearly $60 \%$ of the answers to the task in reading material were found in texts. Questions such as "Give your conclusion or what do you think" could only be found in a few units, for example in unit 3, unit 9, unit 11 , unit 12 , unit 16 to unit 20, and unit 22 to unit 28. Only in Unit 16, students were given the freedom to explain about "How can you describe the economic and social life in Malang?" If these kinds of questions were presented carefully, it could stimulate students to create or produce original thoughts based on their respective abilities.

\section{B. Writing}

The themes used in writing materials were very diverse. Each unit had a different material theme, the higher the unit, the higher the difficulty level of the theme discussed. For example, in unit 1, the theme of writing that was learned was how to write an autobiography. The complexity of the writing task began to change as it entered Unit 20 and above. Here, the writing models for students were at the conceptual stage, for example writing opinions and essays. At the $\mathrm{C} 1$ or remembering level, the writing patterns were in the form of sentence structures, sentence forms, and models concerning sentences. For example, in Unit 2 entitled 'Describing a place', students were given a description or were introduced (recognizing) about the structure of a descriptive sentence. The writing materials were not only limited to recognizing, but it had also classified which parts of the sentences were the identification sentences, and which sentences were descriptive sentences. This sentence structure classification process was identified as the second level of Bloom's Taxonomy, namely understanding (C2).

At the application stage (C3), the learning materials that have been received by students were expected to be implemented by students. Every assignment in the textbook always asked students to rewrite the given material. For example, writing invitation material on unit 6 of the ESP textbook. In task 5, students were 

write this invitation letter was part of applying. Next was the stage of analyzing (C4). Students were considered capable of analyzing when they could make a simple comparison of the presented problems. For example, in task 5 unit 15, there was a comparison diagram of education costs in the regions of Malang and Yogyakarta from 2012 to 2015 . From this diagram, students were asked to write 8 comparative sentences The next level was evaluating (C5) which meant making judgments based on predetermined criteria and standards. After being taught how to write news, the lecturer asked students to write news related to economic issues that occurred in each student's hometown. The last part of the Bloom's Taxonomy cognitive domain was creating (C6). The given writing assignment forced students to produce their written work, for example writing invitation letters, writing company profiles, writing proposal letters, writing opinions to write their curriculum vitae $(\mathrm{CV})$.

\section{Speaking}

The speaking material was the last part of the ESP book: "English Economic and Developmental Studies". Its content was a continuation of the writing material. In Unit 1, for example, in the writing section, students were taught how to write an autobiography in brief (p. 7). Later on, for the speaking part, they were asked to introduce themselves using the patterns that had been taught in the biographical writing material. At the C1 level, the keywords to remember were recognizing and retrieving. Recognizing in the speaking material was similar to writing material. However, the examples used were made differently. In speaking material, students are still introduced to the sentence structure. The structure that forms the introduction sentence is divided into introduction, hobbies, and future dreams.

At the C2 level, namely understand its main characteristic was centered on the following words: classifying, interpreting, summarizing, comparing, and explaining. For example, in the self-introduction, the first question asked was "What is your name?" 'Based on the answer classification, the answer that must be given by students was their own name. For the C3 level (apply) from the beginning, students had been asked to practice (apply). Once they completed the exercises, they were required to also practice the material in front of the class. The demand for speaking in front of the class indirectly made students comparing their abilities with other students and evaluate their lack in speaking English. At this stage, there were two taxonomic levels in one event; analyze (C4) and evaluate (C5). When students could evaluate themselves and improve their way of speaking, students would have a broader context of conversation than the material that had been given (creating something). For example, in the speaking material for Unit 21, Task 8, students were given 6 empty boxes to be filled in with two-way conversation under the theme of making and taking reservation.

\section{Conclusion}

Based on the discussion in the analysis and findings, the author can conclude several things. As stipulated in Government Regulation No. 19 of 2005 related to National Education Standards, the presentation of textbooks can be accessed from several things, including (1) encouraging student involvement in active learning (2) linkages between chapters, between sub chapters, and between concepts, (3) integration/harm ony between concepts, and (4) material presented contextually. Coherently, starting from units 1 to unit 28, this textbook uses the same material patterns: reading, writing, and speaking. In addition, there is also a continuity between the materials, namely between writing and speaking. In unit 3, for example, for writing materials, students are asked to write daily activities. Meanwhile, for speaking material of the same unit, they are asked to inform the other class members about these daily activities (telling daily activities). This kind of continuity also occurs in unit 4 and the following units.

Furthermore, from the available material, the reading, speaking, and writing activities, always encourage student involvement. Thus, this kind of sequence then can affect students cognitively. According to the researcher, this textbook has fulfilled all of Bloom's cognitive domains. For example, in relation to students' 

presented in the text. The second example is the word 'exchange' in Unit 1, task 1. Students are asked to look for synonyms for the word which have similar meaning with words fond in the reading text. Based on the Bloom Taxonomy point of view, the presentation of material in the textbook actually has passed several levels of taxonomy, namely remembering, understanding, analyzing, and applying. When students see the word 'exchange' in the sentence, of course, the process of remembering and understanding simultaneously has occurred. Students remember the learning patterns that they have been done previously, and understand the meaning of the word inside the sentence. If students are already at the understanding stage, then they will begin to analyze the sentence until they come to conduct conclusion. Thus, the application is in the form of problem solving.

In other units such as units 18,20 , and 22 , students are asked to write news, opinions, and speeches. These activities certainly force students' ability to create their own authentic work as well as material for evaluation both for themselves and for lecturers (cognitive level of evaluation and creation). The learning outcomes, actually have been written at the beginning of the lesson and are divided into three parts, namely reading, speaking, and writing. For reading achievement, there are 3 important achievements: (1) students can answer all the questions related to the text, (2) students can find the information implied in the text, (3) students can explore the meaning of each keyword in the text. On the other hand, the achievement for writing and speaking is that students can write autobiographies and can introduce themselves.

\section{References}

Almerico, G. M., \& Baker, R. K. (2004). Bloom's Taxonomy Illustrative Verbs: Developing a Comprehensive List for Educator Use. Florida Association of Teacher Educators Journal, 1(4), 110. Retrieved from http://www.fate1.org/journals/2004/almerico1.pdf.

Anderson, L. W., \& Krathwohl, D. R. (Eds.). (2001). A taxonomy for learning, teaching, and assessing: A revision of Bloom's taxonomy of educational objectives. New York: Longman.

Bell, J., \& Gower, R. (1998). 'Writing course materials for the world: A great compromise'. In Materials Development in Language Teaching. Cambridge (pp. 116-129). Cambridge: Cambridge University Press.

Block, D. (1991). Some thoughts on DIY materials design. ELT Journal, 45(3), $211-21$. https://doi.org/10.1093/elt/45.3.211 (Cambridge Language Teaching Library) Brian TomlinsonMaterials Development in Language Teaching-Cambridge University Press (2011).pdf. (n.d.)

Cunningsworth, A. (1995). Choosing Your Coursebook. Oxford: Heinemann.

Darmawan, I. P. A., \& Sujoko, E. (2013). Revisi Taksonomi Pembelajaran Benyamin S. Bloom. Satya Widya, 29(1), 30. https://doi.org/10.24246/j.sw.2013.v29.i1.p30-39

Enghoff, H. (2009). What is taxonomy? - An overview with myriapodological examples. Soil Organism, 81(3), 441-451.

Hutchinson, Tom, \& Torres, E. (1994). The textbook as agent of change. ELT Journal, 48(4), 315-328. https://doi.org/10.1093/elt/48.4.315

Hutchinson, T. (1987). 'What's underneath?: An Interactive View of Materials Evaluation. In ELT Documents 126. ELT Textbooks and Materials: Problems in Evaluation and Development. London: Modern English Publications/The British Council.

McDonough, J., \& Shaw, C. (1993). Materials and Methods in ELT. Oxford: Blackwell.

Pemerintah, P. (2005). Standar Nasional Pendidikan. Kemdikbud. Retrieved from https://jdih.kemdikbud.go.id/arsip/PP_tahun2005_nomor19\%20(Standar\%20Nasional\%20Pendidik an).pdf

Sugiyono, P. (2010). Metode Penelitian Kuantitatif, Kualitatif, dan R\&D. Bandung: CV Alfabeta. 
Kinanti, L. P., \& Sudirman, S. (2018). Analisis Kelayakan Isi Materi dari Komponen Materi Pendukung 123 Pembelajaran Dldalam Buku Teks Mata Pelajaran Sosiologi Kelas XI SMA Negeri di Kota Bandung. SOSIETAS, 7(1). https://doi.org/10.17509/sosietas.v7i1.10347

Tarigan, H. G., \& Tarigan, D. (2009). Telaah Buku Teks Bahasa Indonesia. Bandung: Percetakan Angkasa.

Tomlinson, Brian. (2011). Materials Development in Language Teaching (Second edition). United Kingdom: Cambridge University Press.

Tomlinson, Brian. (2012). Materials development for language learning and teaching. Language Teaching, 45(2), 143-179. https://doi.org/10.1017/S0261444811000528

Yang, Y. (2010). Predikat dalam Bahasa Indonesia dan Bahasa Mandarin. Universitas Sebelas Maret. 